\title{
Peculiarities of Ag metallic nanoparticles formation in alkaline and alkaline-earth tetraborate glasses
}

\author{
R.M.Dutka, V.T.Adamiv, Ya.V.Burak, \\ R.V.Gamernyk*, I.M.Teslyuk \\ O.Vlokh Institute of Physical Optics, 23 Dragomanov Str., \\ 79005 Lviv, Ukraine \\ *I.Franko National University, 8 Kyrylo and Methodiy Str., \\ 79005 Lviv, Ukraine
}

Received December 11, 2014

Investigations of alkaline $\mathrm{Li}_{2} \mathrm{~B}_{4} \mathrm{O}_{7}: \mathrm{Ag}$ and alkaline-earth $\mathrm{CaB}_{4} \mathrm{O}_{7}: \mathrm{Ag}$ tetraborate glasses with $\mathrm{Ag}$ nanoparticles (Ag NPs) formed by thermal treatment in vacuum have been performed. It is ascertained that in volumes of the both glasses a small number of Ag NPs is formed, whereas their main mass is concentrated near the samples surface. It is obtained from the plasmon resonance results that, under the same annealing conditions, concentration of the $\mathrm{Ag} \mathrm{NPs}$ in the near-surface layer of $\mathrm{CaB}_{4} \mathrm{O}_{7}: \mathrm{Ag}$ glass is appreciably smaller than in the near-surface layer of $\mathrm{Li}_{2} \mathrm{~B}_{4} \mathrm{O}_{7}: \mathrm{Ag}$ glass. This peculiarity is explained by difference between contributions of alkaline $\mathrm{Li}^{+}$and alkaline-earth $\mathrm{Ca}^{2+}$ ions to processes of the Ag NPs formation in respective tetraborate glass.

Keywords: borate glasses, nonlinear refractive index, Ag nanoparticles, plasmon resonance.

Проведены исследования щелочного $\mathrm{Li}_{2} \mathrm{~B}_{4} \mathrm{O}_{7}: \mathrm{Ag}$ и щелочноземельного $\mathrm{CaB}_{4} \mathrm{O}_{7}: \mathrm{Ag}$ тетраборатных стекол с сформированными термической обработкой в вакууме наночастицами $\mathrm{Ag}(\mathrm{HЧ} \mathrm{Ag})$. Установлено, что в объемах обоих стекол формируется небольшое количество НЧ $\mathrm{Ag}$, тогда как основная их масса концентрируется у поверхности образцов. По результатам исследований плазмонного резонанса установлено, что при одинаковых условиях отжига концентрация $\mathrm{HЧ} \mathrm{Ag}$ в приповерхностном слое $\mathrm{CaB}_{4} \mathrm{O}_{7}: \mathrm{Ag}$ стекла ощутимо меньше, чем в приповерхностном слое $\mathrm{Li}_{2} \mathrm{~B}_{4} \mathrm{O}_{7}: \mathrm{Ag}$ стекла. Эта особенность объясняется разницей вкладов щелочного $\mathrm{Li}^{+}$и щелочноземельного $\mathrm{Ca}^{2+}$ ионов в процессы формирования $\mathrm{HЧ} \mathrm{Ag}$ в соответствующем тетраборатном стекле.

Особливості формування металічних наночастинок $\mathrm{Ag}$ в лужних $\mathrm{i}$ лужноземельних тетраборатних стеклах. Р.М.Дутка, В.Т Адалів, Я.В.Бурак, Р.В.Гамерник, І.М.Теслюк.

Проведено дослідження лужного $\mathrm{Li}_{2} \mathrm{~B}_{4} \mathrm{O}_{7}: \mathrm{Ag}$ і лужноземельного $\mathrm{CaB}_{4} \mathrm{O}_{7}: \mathrm{Ag}$ тетраборатних стекол із сформованими термічною обробкою у вакуумі наночастинками Ag (НЧ Ag). Встановлено, що в об’ємах обох стекол формується невелика кількість НЧ $\mathrm{Ag}$, тоді як основна їх маса концентрується біля поверхонь зразків. За результатами досліджень плазмонного резонансу встановлено, що за однакових умов відпалу концентрація НЧ $\mathrm{Ag}$ у приповерхневому шарі $\mathrm{CaB}_{4} \mathrm{O}_{7}: \mathrm{Ag}$ скла $є$ відчутно меншою, ніж у приповерхневому шарі $\mathrm{Li}_{2} \mathrm{~B}_{4} \mathrm{O}_{7}: \mathrm{Ag}$ скла. Ця особливість пояснюється різницею вкладів лужного $\mathrm{Li}^{+}$i лужноземельного $\mathrm{Ca}^{2+}$ йонів у процеси формування $\mathrm{HЧ} \mathrm{Ag}$ у відповідному тетраборатному склі. 


\section{Introduction}

Nanocomposite materials, whose basis is consisted of metallic nanoparticles (MNPs) of noble metals ( $\mathrm{Au}, \mathrm{Ag}, \mathrm{Pt}$ ) in dielectric media, are the object of significant attention in recent years. This is caused by large influence of the MNPs on linear and nonlinear susceptibilities of dielectric matrix [1-3], radiative recombination [4] and giant surface enhanced Raman scattering (SERS) $[5,6]$. Prospects for development of optical switches with ultra-short time response, limiters of optical laser beam intensity for synchronization of the laser modes [7-10], chemical and biochemical sensors caused dominantly by plasmon resonances [11] on the basis of such nanocomposite materials stimulate investigations in this domain of nanotechnologies.

The main attention among abovementioned noble materials is paid to silver $(\mathrm{Ag})$ in process of the MNPs formation in different glass matrices, for example [12-14]. Doping of glasses by $\mathrm{Ag}^{+}$ions with their next reducing to neutral $\mathrm{Ag}^{0}$ condition in the glass matrix by means of thermal treatment in reducing atmosphere [12] is the main method of Ag NPs formation.

Borate glasses, the basis of which is boron anhydride $\mathrm{B}_{2} \mathrm{O}_{3}$ with its tendency to polycondensation [15], can be prospective for $\mathrm{Ag} \mathrm{NPs}$ formation. The borate glasses structurally consist of boroxole groups which are joined by the bridge oxygen atoms that makes their structure enough open. These boroxole groups make the borate glass structure more open near the glass transition temperature $T_{g}[16,17]$ that simplifies the process of $\mathrm{Ag}$ NPs formation.

An important advantage of borate compounds as the glass matrix for Ag NPs formation, is their proper nonlinear optical properties which are defined by high values of nonlinear susceptibilities of boroxole complexes [18, 19]. And plasmon resonance on Ag NPs in borate glasses can influence essentially on their nonlinear properties that makes them potentially very prospective for photonics [20].

$\mathrm{Ag}$ NPs formation on surface of $\mathrm{Li}_{2} \mathrm{~B}_{4} \mathrm{O}_{7}$ :Ag glass from $\mathrm{Li}_{2} \mathrm{O}-\mathrm{B}_{2} \mathrm{O}_{3}$ system by annealing in reducing atmosphere without application of reducing admixtures was successful and permitted to observe powerful surface plasmon resonance $[21,22]$. But, since presence of $\mathrm{Li}$ in $\mathrm{Li}_{2} \mathrm{~B}_{4} \mathrm{O}_{7}$ glass makes it somewhat sensitive to moisture. There- fore it is necessary to pay attention to another borate glasses, in particular, tetraborate $\mathrm{CaB}_{4} \mathrm{O}_{7}$ glass from $\mathrm{CaO}-\mathrm{B}_{2} \mathrm{O}_{3}$ system [23]. The substitution of univalent $\mathrm{Li}^{+}$ions by bivalent $\mathrm{Ca}^{2+}$ ones causes their very low hygroscopic nature [24].

This work is devoted to formation of $\mathrm{Ag}$ NPs by thermal treatment and comparative investigation of the optical properties, in particular, plasmon resonance bands in alkaline and alkaline-earth tetraborate glasses by giving two representatives of such glasses: alkaline $\mathrm{Li}_{2} \mathrm{~B}_{4} \mathrm{O}_{7}: A g$ glass $(98.0$ $\left.\mathrm{Li}_{2} \mathrm{~B}_{4} \mathrm{O}_{7}-2.0 \quad \mathrm{Ag}_{2} \mathrm{O}\right)$ and alkaline-earth $\mathrm{CaB}_{4} \mathrm{O}_{7}$ :Ag glass (98.0 $\left.\mathrm{CaB}_{4} \mathrm{O}_{7}-2.0 \mathrm{Ag}_{2} \mathrm{O}\right)$.

\section{Experimental}

For preparation of $\mathrm{Li}_{2} \mathrm{~B}_{4} \mathrm{O}_{7}: \mathrm{Ag}$ and $\mathrm{CaB}_{4} \mathrm{O}_{7}: \mathrm{Ag}$ glasses there were taken highly pure lithium carbonate $\mathrm{Li}_{2} \mathrm{CO}_{3}$ or calcium carbonate $\mathrm{CaCO}_{3}$, boric acid $\mathrm{H}_{3} \mathrm{BO}_{3}$ and silver nitrate $\mathrm{AgNO}_{3}$. Synthesis of $\mathrm{Li}_{2} \mathrm{~B}_{4} \mathrm{O}_{7}$ or $\mathrm{CaB}_{4} \mathrm{O}_{7}$ compound firstly was performed:

1) for $\mathrm{Li}_{2} \mathrm{~B}_{4} \mathrm{O}_{7}$ compound synthesis the mixture of initial chemicals prepared by stoichiometric $\mathrm{Li}_{2} \mathrm{O} \cdot 2 \mathrm{~B}_{2} \mathrm{O}_{3}$ composition was placed into ceramic crucible and $\mathrm{Li}_{2} \mathrm{~B}_{4} \mathrm{O}_{7}$ powder with $T_{\text {melt }}=1198 \mathrm{~K}$ (congruently) was obtained by the method of multi-graded temperature synthesis according to the following chemical reaction:

$\mathrm{Li}_{2} \mathrm{CO}_{3}+4 \mathrm{H}_{3} \mathrm{BO}_{3} \rightarrow \mathrm{Li}_{2} \mathrm{~B}_{4} \mathrm{O}_{7}+\mathrm{CO}_{2} \uparrow+6 \mathrm{H}_{2} \mathrm{O} \uparrow ;$

2) for $\mathrm{CaB}_{4} \mathrm{O}_{7}$ synthesis the mixture of initial chemicals prepared by stoichiometric $\mathrm{CaO} \cdot 2 \mathrm{~B}_{2} \mathrm{O}_{3}$ composition was placed into ceramic crucible and $\mathrm{CaB}_{4} \mathrm{O}_{7}$ powder with $T_{\text {melt }} \approx 1260 \mathrm{~K}$ (incongruentlty) was obtained by the method of multi-graded temperature synthesis according to the following chemical reaction:

$$
\mathrm{CaCO}_{3}+4 \mathrm{H}_{3} \mathrm{BO}_{3} \rightarrow \mathrm{CaB}_{4} \mathrm{O}_{7}+\mathrm{CO}_{2} \uparrow+6 \mathrm{H}_{2} \mathrm{O} \uparrow \text {. }
$$

Two mole percent of $\mathrm{AgNO}_{3}$ was added to these powders. $\mathrm{Li}_{2} \mathrm{~B}_{4} \mathrm{O}_{7}: \mathrm{Ag}$ glass was prepared by melting technique in $\mathrm{Al}_{2} \mathrm{O}_{3}$ crucible in air at $1270 \mathrm{~K}$, and $\mathrm{CaB}_{4} \mathrm{O}_{7}: \mathrm{Ag}$ glass was prepared at $1320 \mathrm{~K}$. The melts were homogenized during $0.5 \mathrm{~h}$ and cooled during one hour down to temperature $673 \mathrm{~K}$ followed by inertial cooling down to the room temperature.

For formation of the near-surface layer from $\mathrm{Ag}$ NPs the sample $\mathrm{Li}_{2} \mathrm{~B}_{4} \mathrm{O}_{7}: \mathrm{Ag}$ was annealed at temperature $710 \pm 5 \mathrm{~K}$ (the glass transition temperature for $\mathrm{Li}_{2} \mathrm{~B}_{4} \mathrm{O}_{7}$ glass $T_{g} \approx 713 \mathrm{~K}$ [25]) and the sample $\mathrm{CaB}_{4} \mathrm{O}_{7}$ 
Table 1. Parameters of undoped borate glasses

\begin{tabular}{||c|c|c|c|c|c|c||}
\hline & $d, \mathrm{~g} / \mathrm{cm}^{3}$ & $\alpha, \mathrm{K}^{-1}$ & $H, \mathrm{~N} / \mathrm{mm}^{2}$ & $\begin{array}{c}\text { Boroxole } \\
\text { group }\end{array}$ & $N_{b g}, \mathrm{~cm}^{-3}$ & $n_{2}, \mathrm{~cm}^{2} / \mathrm{W}$ \\
\hline $\mathrm{Li}_{2} \mathrm{~B}_{4} \mathrm{O}_{7}$ & 2.2 & $6.9 \cdot 10^{-6}$ & 5164.6 & $2 \mathrm{BO}_{3}+2 \mathrm{BO}_{4}$ & $8 \cdot 10^{21}$ & $-9.9 \cdot 10^{-9}$ \\
\hline $\mathrm{CaB}_{4} \mathrm{O}_{7}$ & 2.5 & $3.6 \cdot 10^{-6}$ & 8369.2 & $4 \mathrm{BO}_{3}+4 \mathrm{BO}_{4}$ & $7.6 \cdot 10^{21}$ & $-1.4 \cdot 10^{-9}$ \\
\hline
\end{tabular}

glass was annealed at temperature $\sim 870 \mathrm{~K}$ (the glass transition temperature for $\mathrm{CaB}_{4} \mathrm{O}_{7}$ glass $T_{\mathrm{g}} \approx 883 \mathrm{~K}$ [25]) during $2 \mathrm{~h}$ in vacuum $\left(<10^{-4}\right.$ Torr with titanium getter) or in air atmosphere.

Plates with dimensions of $\sim 10 \times 7 \times 1 \mathrm{~mm}^{3}$ were cut from obtained glasses, and their surfaces were grinded and polished. Transmission spectra were measured using set-up, which included MDR-23 monochromator and personal computer. Halogen incandescent lamp was used as a light source, and PMT79 photomultiplier was exploited as detector in the single-photon regime ensuring linearity of the signal registration in the range of $10^{2}-10^{6}$ photons per second. Traditional single-beam Z-scan method developed by Sheik-Bahae et al. [26, 27] was used for investigations of the nonlinear optical properties of $\mathrm{Li}_{2} \mathrm{~B}_{4} \mathrm{O}_{7}: \mathrm{Ag}$ and $\mathrm{CaB}_{4} \mathrm{O}_{7}: \mathrm{Ag}$ glasses with formed $\mathrm{Ag}$ NPs. Measurements were performed at the room temperature. Second harmonic radiation from continuous neodymium laser with diode pumping, operating on wavelength $532 \mathrm{~nm}$, was used. Output power of the laser beam was $45 \mathrm{~mW}$. Parameters of the focused laser beam were in agreement with principal demands of Z-scan experiment: $2 \omega_{0}=22.3 \mu \mathrm{m}\left(\omega_{0}-\right.$ radius of the Gauss beam in focus); $b=n \pi \omega_{0} / \lambda=$ $1.197 \mathrm{~mm}(b$ - diffraction length in the Rayleigh range), laser beam power density in focus $I_{0}=1.04 \cdot 10^{4} \mathrm{~W} / \mathrm{cm}^{2}$.

\section{Results and discussion}

The main parameters of undoped $\mathrm{Li}_{2} \mathrm{~B}_{4} \mathrm{O}_{7}$ and $\mathrm{CaB}_{4} \mathrm{O}_{7}$ glass matrices were determined, in particular, density $d$ (hydrostatic method), thermal expansion coefficient $\alpha$ (dilatometry method), microhardness $H$ (the Whisker method). These parameters at the same time the type of boroxole group, number of boroxole groups in $\mathrm{cm}^{3} N_{b g}$, and nonlinear refractive index $n_{2}$ are presented in Table 1. As it is seen from Table 1, substitution of univalent $\mathrm{Li}^{+}$ions by bivalent $\mathrm{Ca}^{2+}$ ones changes significantly the main parameters of the tetraborate glass. Significantly larger density $d$ of $\mathrm{CaB}_{4} \mathrm{O}_{7}$ glass in comparison with $\mathrm{Li}_{2} \mathrm{~B}_{4} \mathrm{O}_{7}$ glass can be easy ex- plained by significantly larger atomic mass of Ca ( 40) than mass of two Li atoms ( 14). And differences in coefficients $\alpha$ and microhardnesses $H$ are defined by differences in electron bonds in structure of $\mathrm{Li}_{2} \mathrm{~B}_{4} \mathrm{O}_{7}$ and $\mathrm{CaB}_{4} \mathrm{O}_{7}$ glasses.

As it is seen from Table 1 , the crystal structure of $\mathrm{Li}_{2} \mathrm{~B}_{4} \mathrm{O}_{7}$ and $\mathrm{CaB}_{4} \mathrm{O}_{7}$ compounds consists of very similar boroxole groups. So, $\mathrm{Li}_{2} \mathrm{~B}_{4} \mathrm{O}_{7}$ structure is formed only from tetraborate $\left(2 \mathrm{BO}_{3}+2 \mathrm{BO}_{4}\right)$ boroxole groups, which refer to anion $\left[\mathrm{B}_{4} \mathrm{O}_{9}\right]^{6-}[28,29]$, and the structure of $\mathrm{CaB}_{4} \mathrm{O}_{7}$ is formed from somewhat more complex boroxole groups $\left(4 \mathrm{BO}_{3}+4 \mathrm{BO}_{4}\right):$ one tetraborate $\left(2 \mathrm{BO}_{3}+\right.$ $\left.2 \mathrm{BO}_{4}\right)$ and one triborate $\left(2 \mathrm{BO}_{3}+\mathrm{BO}_{4}\right)$ boroxole group attached to it by additional tetrahedron $\mathrm{BO}_{4}$ that form together anion $\left[\mathrm{B}_{8} \mathrm{O}_{14}\right]^{4-}[30]$. And since in publication [31] it was ascertained that dominant boroxole structural elements of corresponding tetraborate crystal are clearly observed in the glass structure, then one can make a conclusion that significant differences in values $\alpha$ and $H$ in $\mathrm{Li}_{2} \mathrm{~B}_{4} \mathrm{O}_{7}$ and $\mathrm{CaB}_{4} \mathrm{O}_{7}$ glasses are caused by differences in $\mathrm{Li}-\mathrm{O}$ and $\mathrm{Ca}-\mathrm{O}$ bonds in their structure. This conclusion is confirmed by the authors of recent publication [24], who investigated the changes of $\mathrm{CaB}_{4} \mathrm{O}_{7}$ glass properties under particular substitution of $\mathrm{Ca}$ by $\mathrm{Li}$ (90 $\mathrm{CaB}_{4} \mathrm{O}_{7}-10 \mathrm{Li}_{2} \mathrm{O}$ ) and explained the effect of $\mathrm{Li}^{+}$on characteristic of $\mathrm{CaB}_{4} \mathrm{O}_{7}$ glass in terms of the $\mathrm{Li}-\mathrm{O}$ bonding interaction, since the monovalent $\mathrm{Li}^{+}$ions produce the lower cross-linking efficiency when compared to the bivalent $\mathrm{Ca}^{2+}$ ion.

Appearance of corresponding characteristic plasmon bands in the absorption spectra is the most cogent argument for presence of the MNPs in the glass matrices. And for Ag NPs these bands are in the range of 360-500 nm [32]. In Fig. 1 and 2 one can observe transmission spectra of our $\mathrm{Li}_{2} \mathrm{~B}_{4} \mathrm{O}_{7}: \mathrm{Ag}$ and $\mathrm{CaB}_{4} \mathrm{O}_{7}: \mathrm{Ag}$ glasses before and after annealing in vacuum. Comparative analysis of these spectra shows that after annealing of our glass samples in vacuum there appear the sharply defined absorption plasmon bands in transmission 


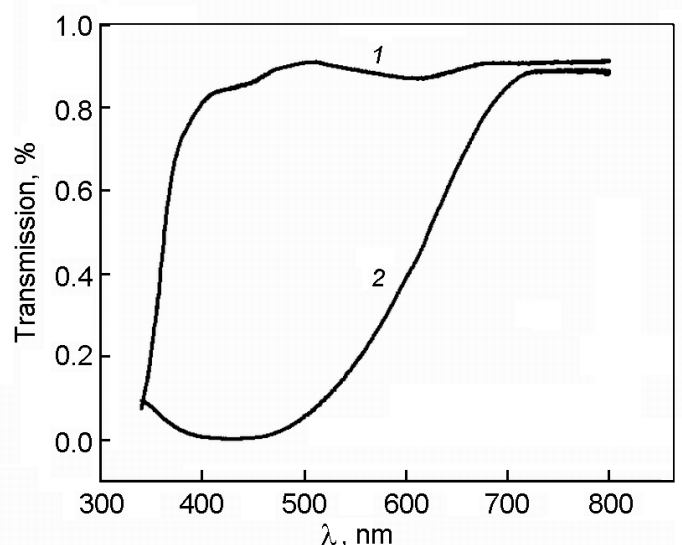

Fig. 1. Transmission spectra of $\mathrm{Li}_{2} \mathrm{~B}_{4} \mathrm{O}_{7}: \mathrm{Ag}$ glass: 1) without annealing or annealed in air; 2) annealed in vacuum.

spectra with maximums near 400-420 nm (Fig. 1, curve 2 and Fig. 2, curve 2), indicative of $\mathrm{Ag}$ NPs existence in these samples. The plasmon absorption band in $\mathrm{Li}_{2} \mathrm{~B}_{4} \mathrm{O}_{7}: \mathrm{Ag}$ glass (Fig. 1, curve 2) is especially intensive and wide after annealing in vacuum, while in the $\mathrm{CaB}_{4} \mathrm{O}_{7}: \mathrm{Ag}$ glass sample the plasmon band stands out very sharply, but has considerably smaller intensity. From this one can make concrete conclusion that number of $\mathrm{Ag} \mathrm{NPs}$ in $\mathrm{Li}_{2} \mathrm{~B}_{4} \mathrm{O}_{7}: \mathrm{Ag}$ glass formed by annealing in vacuum under the same conditions is considerably larger than in $\mathrm{CaB}_{4} \mathrm{O}_{7}: \mathrm{Ag}$ glass.

Estimation of $\mathrm{Ag} \mathrm{NPs}$ radii in the annealed $\mathrm{Li}_{2} \mathrm{~B}_{4} \mathrm{O}_{7}: \mathrm{Ag}$ and $\mathrm{CaB}_{4} \mathrm{O}_{7}: \mathrm{Ag}$ glasses can be made from relationship $R=$ $V_{F} / \Delta \omega_{1 / 2}$, where $V_{F}=1.39 \cdot 10^{6} \mathrm{~m} / \mathrm{s}$ - velocity of the Fermi electrons in silver, and $\Delta \omega_{1 / 2}$ - band half-width according to the Mie theory approximation [33]. The results of calculations for $R$ are given in Table 2 .

In Fig. $3 \mathrm{Z}$-scan spectra are presented for $\mathrm{Li}_{2} \mathrm{~B}_{4} \mathrm{O}_{7}: \mathrm{Ag}$ and $\mathrm{CaB}_{4} \mathrm{O}_{7}:$ Ag glasses annealed in vacuum. The Z-scan experiment permits to calculate the nonlinear refractive index $n_{2}$, which enters into known expression for the total refractive coefficient $n=n_{0}+$ $n_{2}|E|^{2}$, where $n_{0}$ - linear refractive index, and $E$ denotes magnitude of electromagnetic field strength of the laser radiation. Calculation of the nonlinear refractive index $n_{2}$ from normalized Z-scan spectra was performed using formula $n_{2}=\Delta \Phi_{0} / k L_{e f f} I_{0}$ [33], and the results of calculations are shown in Table 2. Values $n_{2}$ for undoped $\mathrm{Li}_{2} \mathrm{~B}_{4} \mathrm{O}_{7}$ and $\mathrm{CaB}_{4} \mathrm{O}_{7}$ glasses, obtained analogously from their Z-scan spectra, are given in Table 1 and indicate about the presence of intrinsic nonlinear properties in these

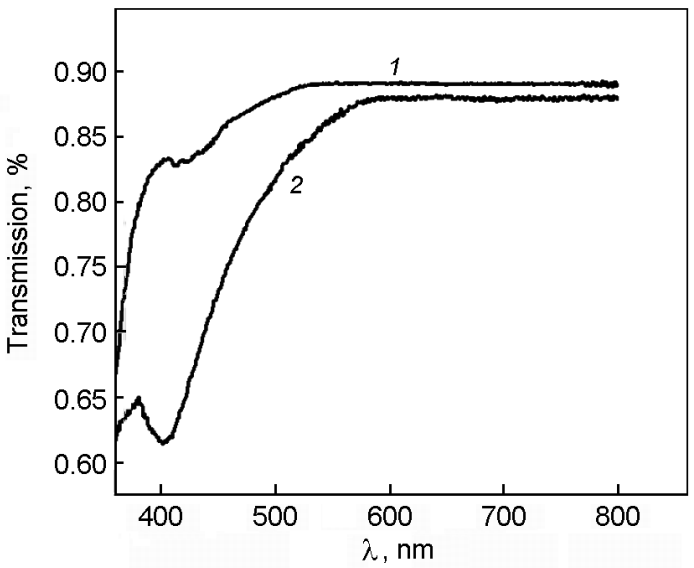

Fig. 2. Transmission spectra of $\mathrm{CaB}_{4} \mathrm{O}_{7}: \mathrm{Ag}$ glass: 1) without annealing; 2) annealed in vacuum.

Table 2. Results of calculations of Ag NPs radii $R$ and nonlinear refractive indices $n_{2}$ of active layer with $\mathrm{Ag}$ NPs in borates glasses

\begin{tabular}{|c|c|c|c||}
\hline Glass & & $R, \mathrm{~nm}$ & $n_{2}, \mathrm{~cm}^{2} / \mathrm{W}$ \\
\hline $\mathrm{Li}_{2} \mathrm{~B}_{4} \mathrm{O}_{7}: \mathrm{Ag}$ & $\begin{array}{c}\text { without } \\
\text { annealing }\end{array}$ & - & $-3.8 \cdot 10^{-9}$ \\
\cline { 2 - 4 } & $\begin{array}{c}\text { annealed in } \\
\text { vacuum }\end{array}$ & 1.5 & $5.7 \cdot 10^{-6 *}$ \\
\hline $\mathrm{CaB}_{4} \mathrm{O}_{7}: \mathrm{Ag}$ & $\begin{array}{c}\text { without } \\
\text { annealing }\end{array}$ & - & $-1.2 \cdot 10^{-9}$ \\
\cline { 2 - 4 } & $\begin{array}{c}\text { annealed in } \\
\text { vacuum }\end{array}$ & 1.2 & $9.6 \cdot 10^{-6 *}$ \\
\hline
\end{tabular}

* calculations for $n_{2}$ were performed for thickness of active layer with Ag NPs $2 \times L_{i}=L_{e f f}=$ $3.6 \cdot 10^{-4} \mathrm{~cm}$

glasses, caused by nonlinear susceptibilities of their boroxole complexes [18, 19]. As it is seen from Tables 1 and 2, the nonlinear refractive index $n_{2}$ of undoped $\mathrm{Li}_{2} \mathrm{~B}_{4} \mathrm{O}_{7}$ and $\mathrm{CaB}_{4} \mathrm{O}_{7}$ and doped unannealed $\mathrm{Li}_{2} \mathrm{~B}_{4} \mathrm{O}_{7}: \mathrm{Ag}$ and $\mathrm{CaB}_{4} \mathrm{O}_{7}: \mathrm{Ag}$ glasses are negative, but have somewhat different absolute values. After annealing, which leads to formation of $\mathrm{Ag} \mathrm{NPs}$, the nonlinear properties of the both glasses change cardinally - the nonlinear refractive index $n_{2}$ becomes positive and larger for some orders of magnitude (Table 2).

Distribution of the $\mathrm{Ag} \mathrm{NPs}$ in $\mathrm{Li}_{2} \mathrm{~B}_{4} \mathrm{O}_{7}: \mathrm{Ag}$ and $\mathrm{CaB}_{4} \mathrm{O}_{7}: \mathrm{Ag}$ glass samples annealed in vacuum is an important question. The atomic-force microscope investigations of the $\mathrm{Li}_{2} \mathrm{~B}_{4} \mathrm{O}_{7}: \mathrm{Ag}$ glasses surface topology allowed to make a conclusion that the Ag NPs formed by annealing of $\mathrm{Li}_{2} \mathrm{~B}_{4} \mathrm{O}_{7}: \mathrm{Ag}$ glasses 
in hydrogen and in vacuum are concentrated in a thin near-surface layer, so-called $" \mathrm{Li}_{2} \mathrm{~B}_{4} \mathrm{O}_{7}: \mathrm{Ag}+\mathrm{Ag} \mathrm{NPs} "$ interface layer, which is observed in the transmission spectra as intensive plasmon absorption band $[21,22]$. To receive an evidence that after annealing of our $\mathrm{Li}_{2} \mathrm{~B}_{4} \mathrm{O}_{7}: \mathrm{Ag}$ and $\mathrm{CaB}_{4} \mathrm{O}_{7}: \mathrm{Ag}$ glasses in vacuum the $\mathrm{Ag}$ NPs are also concentrated near the samples surface after recording of the transmission spectra (Fig. 1, curve 2 and Fig. 2, curve 2) the layers with thickness of $2 \mu \mathrm{m}$ were mechanically deleted (grinded) from the both their surfaces for guaranteed deliverance from $" \mathrm{Li}_{2} \mathrm{~B}_{4} \mathrm{O}_{7}: \mathrm{Ag}+$ Ag NPs" interface layer. Obtained transmission spectra of the $\mathrm{Li}_{2} \mathrm{~B}_{4} \mathrm{O}_{7}: \mathrm{Ag}$ and $\mathrm{CaB}_{4} \mathrm{O}_{7}: \mathrm{Ag}$ glass samples after deleting of $" \mathrm{Li}_{2} \mathrm{~B}_{4} \mathrm{O}_{7}: \mathrm{Ag}+\mathrm{Ag} \mathrm{NPs"} \mathrm{interface} \mathrm{layer} \mathrm{coin-}$ cided completely with the transmission spectra of these samples recorded before annealing (Fig. 1, curve 1 and Fig. 2, curve 1).

Nevertheless, if to look carefully on our transmission spectra recorded before annealing of the $\mathrm{Li}_{2} \mathrm{~B}_{4} \mathrm{O}_{7}: \mathrm{Ag}$ and $\mathrm{CaB}_{4} \mathrm{O}_{7}: \mathrm{Ag}$ glass samples (Fig. 1, curve 1 and Fig. 2, curve 1) one can see the weak but still noticeable plasmon absorption bands in the neighborhood of $400-450 \mathrm{~nm}$. This indicates the presence of some number of the Ag NPs in volumes of our glass samples, which were not additionally annealed after the glass preparation. It is interesting to note that annealing in air under the same conditions (temperature and anneal time) of the newly prepared samples from $\mathrm{Li}_{2} \mathrm{~B}_{4} \mathrm{O}_{7}: \mathrm{Ag}$ and $\mathrm{CaB}_{4} \mathrm{O}_{7}: \mathrm{Ag}$ glasses does not lead to noticeable changes in the absorption spectra, i.e., these practically coincide with the spectra of unannealed samples (as on Fig. 1, curve 1 and Fig. 2, curve 1). This can mean that some number of the $\mathrm{Ag} \mathrm{NPs}$ is formed in volume of $\mathrm{Li}_{2} \mathrm{~B}_{4} \mathrm{O}_{7}: \mathrm{Ag}$ and $\mathrm{CaB}_{4} \mathrm{O}_{7}: \mathrm{Ag}$ glasses just on the stage of glass formation from corresponding melt in the process of its cooling. And this number of the Ag NPs formed in the volume has time to reach saturation in the process of cooling, because additional annealing does not lead to increasing of their concentration. Almost equal intensities of the plasmon absorption bands of the unannealed $\mathrm{Li}_{2} \mathrm{~B}_{4} \mathrm{O}_{7}: \mathrm{Ag}$ and $\mathrm{CaB}_{4} \mathrm{O}_{7}: \mathrm{Ag}$ glass samples (Fig. 1 , curve 1 and Fig. 2, curve 1) permit to state that the Ag NPs concentration in volumes of the both glasses must be almost the same, although there is more free volume in the $\mathrm{CaB}_{4} \mathrm{O}$ glass than in the $\mathrm{Li}_{2} \mathrm{~B}_{4} \mathrm{O}_{7}$ glass [34]. This can be easily explained: in the volume, at absence of ions-reducers the process of

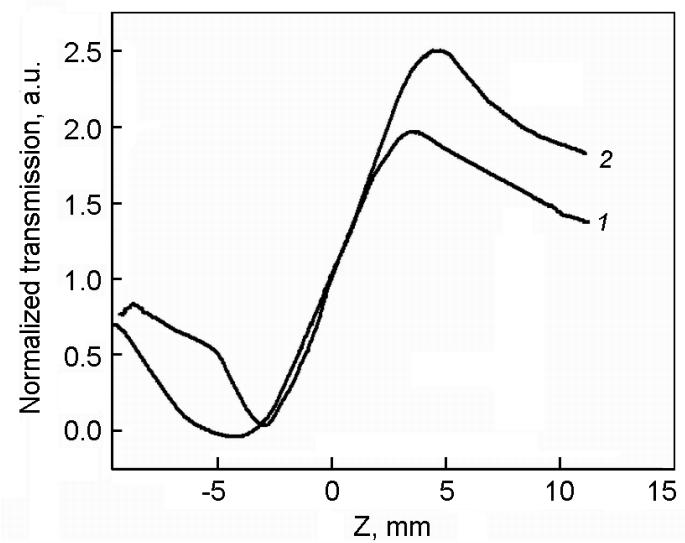

Fig. 3. Z-scan spectra: $1-\mathrm{Li}_{2} \mathrm{~B}_{4} \mathrm{O}_{7}: \mathrm{Ag}$ glass annealed in vacuum; $2-\mathrm{CaB}_{4} \mathrm{O}_{7}: \mathrm{Ag}$ glass annealed in vacuum.

$\mathrm{Ag}^{+}$ions reducing practically does not take place, and this small number of $\mathrm{Ag} \mathrm{NPs}$ in the volume of the glass is formed from the neutral $\mathrm{Ag}$ atoms, which, evidently, are available in it from the moment of synthesis.

Therefore, the main difference between the $\mathrm{Li}_{2} \mathrm{~B}_{4} \mathrm{O}_{7}: \mathrm{Ag}$ and $\mathrm{CaB}_{4} \mathrm{O}_{7}: \mathrm{Ag}$ glasses is seen in the mechanism and efficiency of $\mathrm{Ag}$ NPs formation on/near the surface of the glass samples. Undoubtedly, the process of $\mathrm{Ag}^{+}$ions reducing to neutral $\mathrm{Ag}^{0}$ atoms and the Ag NPs formation takes place by the same mechanism on surface of the glass samples, but with different intensity (velocity). This intensity is defined by ratio of velocities for three main processes, which take place in the glasses at annealing temperature $\left(\sim 713 \mathrm{~K}\right.$ for $\mathrm{Li}_{2} \mathrm{~B}_{4} \mathrm{O}_{7}$ and $\sim 870 \mathrm{~K}$ for $\mathrm{CaB}_{4} \mathrm{O}_{7}$ glasses): 1) velocity of the process $\mathrm{O}^{2-}-2 e=\mathrm{O}^{0}$ on the glass surface and transition of the neutral oxygen atoms into vacuum, where these are absorbed by getter; 2) intensity of $\mathrm{Ag}^{+}$ions reducing to neutral atoms near the glass surface $\left(\mathrm{Ag}^{+}+e=\right.$ $\left.\mathrm{Ag}^{0}\right)$; 3) velocity of $\mathrm{Ag}^{+}$ions diffusion from the glass volume to surface, because in reducing process the concentration of $\mathrm{Ag}^{+}$ions decreases near the surface, and their delivery to near-surface layer takes place owing to diffusion from the sample volume in direction to the surface.

Let us compare successively the passage of all these three processes in the $\mathrm{Li}_{2} \mathrm{~B}_{4} \mathrm{O}_{7}: \mathrm{Ag}$ and $\mathrm{CaB}_{4} \mathrm{O}_{7}: \mathrm{Ag}$ glasses. Therefore, at preparation of the glass samples there is used mechanical treatment (cutting, grinding and polishing), which leads to appearance of well developed network of defects with damaged, in particular, dangling interatomic bonds on surface of the both 
glass samples. If such glass samples are heated in vacuum to temperatures $T_{g}$, then near such defective places the neutral oxygen atom, which is formed from $\mathrm{O}^{2-}\left(\right.$ or $\mathrm{O}^{-}$) ion, can easily lose contact and come from surface of borate glass into vacuum, returning excess electrons to the neighbor $\mathrm{Ag}^{+}$or $\mathrm{Li}^{+}$ions in the $\mathrm{Li}_{2} \mathrm{~B}_{4} \mathrm{O}_{7}: \mathrm{Ag}$ glass, and $\mathrm{Ag}^{+}$or $\mathrm{Ca}^{2+}$ in the $\mathrm{CaB}_{4} \mathrm{O}_{7}: \mathrm{Ag}$ glass, because electron affinity of $\mathrm{O}$ atoms is negative. And velocity of this process must not differ essentially for the $\mathrm{Li}_{2} \mathrm{~B}_{4} \mathrm{O}_{7}: \mathrm{Ag}$ and $\mathrm{CaB}_{4} \mathrm{O}_{7}: \mathrm{Ag}$ glasses, because the basis of their structure is consisted of similar boroxole groups, and $\mathrm{B}-\mathrm{O}$ bonds are definitive in the borate glasses.

However the processes of $\mathrm{Ag}^{+}$ions reducing to neutral $\mathrm{Ag}^{0}$ atoms near the surface of the $\mathrm{Li}_{2} \mathrm{~B}_{4} \mathrm{O}_{7}: \mathrm{Ag}$ and $\mathrm{CaB}_{4} \mathrm{O}_{7}: \mathrm{Ag}$ glasses take place somewhat differently. For the $\mathrm{Li}_{2} \mathrm{~B}_{4} \mathrm{O}_{7}: \mathrm{Ag}$ glass the electrons can be captured by $\mathrm{Li}^{+}\left(\mathrm{Li}^{+}+e=\mathrm{Li}^{0}\right)$ ions, if $\mathrm{Ag}^{+}$ions are absent near position in which the process $\mathrm{O}^{2-}-2 e=\mathrm{O}^{0}$ took place. The captured electron can easily migrate on the neighbor $\mathrm{Li}^{+}$ions until it will be met and captured by $\mathrm{Ag}^{+}$ion. But neutral $\mathrm{Ag}^{0}$ atom will not send so easily the captured electron to neighbor $\mathrm{Li}^{+}$ion, because ionization potential for $\mathrm{Ag} \rightarrow \mathrm{Ag}^{+}=7.6 \mathrm{eV}$, while for $\mathrm{Li} \rightarrow \mathrm{Li}^{+}=$ $5.4 \mathrm{eV}$. Another situation takes place for the $\mathrm{CaB}_{4} \mathrm{O}_{7}: \mathrm{Ag}$ glass: if electron, released by oxygen, is captured by $\mathrm{Ca}^{2+}$ ion but not directly by $\mathrm{Ag}^{+}$ion, then, practically, it will be not delivered, because ionization potential for $\mathrm{Ca}^{+} \rightarrow \mathrm{Ca}^{2+}=11.87 \mathrm{eV}$. If take into account that here we observe an accumulation of negative charge on the sample that will slow down the process $\mathrm{O}^{2-}-2 e=\mathrm{O}^{0}$, then the large difference between the velocities of $\mathrm{Ag}^{+}$ions reducing to neutral atoms near the surface of $\mathrm{Li}_{2} \mathrm{~B}_{4} \mathrm{O}_{7}: \mathrm{Ag}$ and $\mathrm{CaB}_{4} \mathrm{O}_{7}: \mathrm{Ag}$ glasses becomes understandable, in the $\mathrm{CaB}_{4} \mathrm{O}_{7}: \mathrm{Ag}$ glass it is significantly smaller.

In regard to the velocity of $\mathrm{Ag}^{+}$ions diffusion from the glass volume to the surface, where their concentration decreases because of reducing process $\mathrm{Ag}^{+}+e=\mathrm{Ag}^{0}$, one can note that $\mathrm{Ag}^{+}$ions, without doubt, diffuse easier on lithium vacancies $\left(V_{\mathrm{Li}+}\right)$ in the structure of the $\mathrm{Li}_{2} \mathrm{~B}_{4} \mathrm{O}_{7}$ glass, than on $V_{\mathrm{Ca} 2+}$ vacancies in the structure of $\mathrm{CaB}_{4} \mathrm{O}_{7}$ glass. Therefore, the velocity of $\mathrm{Ag}^{+}$ions supply from the glass volume to its surface in the $\mathrm{CaB}_{4} \mathrm{O}_{7}: \mathrm{Ag}$ glasses by means of diffusion also must be significantly smaller.
The neutral $\mathrm{Ag}^{0}$ atoms near the surface can migrate enough easy on the frame structure of the borate glass that gives them a possibility to unite into clusters-nuclei with the next formation of the Ag NPs on these surface defects, the number of which on/near the surface is significantly larger than in the glass volume. Therefore, at annealing in vacuum, the layers with $\mathrm{Ag}$ NPs are formed on the surface and in nearsurface regions of the $\mathrm{Li}_{2} \mathrm{~B}_{4} \mathrm{O}_{7}: \mathrm{Ag}$ and $\mathrm{CaB}_{4} \mathrm{O}_{7}: \mathrm{Ag}$ glass samples. Nevertheless, owing to above described difference between the velocities of the processes, equipped in formation of the Ag NPs, their concentration in the near-surface layers of the $\mathrm{Li}_{2} \mathrm{~B}_{4} \mathrm{O}_{7}: \mathrm{Ag}$ and $\mathrm{CaB}_{4} \mathrm{O}_{7}: \mathrm{Ag}$ glasses differ significantly. For the $\mathrm{CaB}_{4} \mathrm{O}_{7}: \mathrm{Ag}$ glass it is significantly lower that is confirmed by intensity of the plasmon absorption bands (Fig. 1, curve 2 and Fig. 2, curve 2).

\section{Conclusions}

Performed investigations showed that $\mathrm{Ag}$ NPs can be formed both in alkaline $\mathrm{Li}_{2} \mathrm{~B}_{4} \mathrm{O}_{7}: \mathrm{Ag}$ and in alkaline-earth $\mathrm{CaB}_{4} \mathrm{O}_{7}: \mathrm{Ag}$ tetraborate glasses by thermal treatment in vacuum at the glass transition temperature $T_{g}$. And it was observed that almost equal, but not large, number of the Ag NPs is formed in volumes of the both glasses, whereas the major mass of the Ag NPs with size to $2 R \approx 3.0 \mathrm{~nm}$ is concentrated near the surfaces of the glass samples. On the basis of the plasmon resonance results it was made a conclusion that concentration of the $\mathrm{Ag} \mathrm{NPs}$ in the near-surface layer of $\mathrm{CaB}_{4} \mathrm{O}_{7}: \mathrm{Ag}$ glass is significantly smaller than in the near-surface layer of $\mathrm{Li}_{2} \mathrm{~B}_{4} \mathrm{O}_{7}: \mathrm{Ag}$ glass. This peculiarity can be explained by difference between contributions of alkaline $\mathrm{Li}^{+}$and alkaline-earth $\mathrm{Ca}^{2+}$ ions in processes of the Ag NPs formation in corresponding tetraborate glass.

Despite smaller concentration of the $\mathrm{Ag}$ NPs in the near-surface layer of $\mathrm{CaB}_{4} \mathrm{O}_{7}: \mathrm{Ag}$ glass and, respectively, weaker intensity of the plasmon resonance in it, this glass can be very prospective for plasmonics owing to high value of the nonlinear refractive index $n_{2}$ (Table 2) and total nonhygroscopicity.

\section{References}

1. V.M.Shalaev, Phys. Rep., 272, 61 (1996).

2. V.A.Markel, V.M.Shalaev, Phys.Rev.B, 53, 2425 (1996).

3. V.A.Markel, V.M.Shalaev, Phys.Rev.B, 53, 2437 (1996). 
4. L.A.Blanco, F.J.Garcia de Abajo, J.Quant. Spectr.Rad.Transf., 89, 37 (2004).

5. M.I.Stockman, V.M.Shalaev, M.Moskovits et al., Phys. Rev. B, 46, 2821 (1992).

6. S.V.Karpov, V.S.Gerasimov, I.L.Isaev, V.A.Markel, Phys. Rev.B, 72, 2545 (2005).

7. H.Inouye, K.Tanaka, I.Tanahashi et al., Jpn. J.Appl.Phys., 39, 5123 (2000).

8. Y.-P.Sun, J.E.Riggs, H.W.Rollins, R.Guduru, J.Phys.Chem. B, 103, 77 (1999).

9. J.Staromlynska, J.McKay, P.Wilson, J.Appl. Phys., 88, 1726 (2000).

10. K.Wundke, S.Potting, J.Auxier et al., Appl. Phys. Lett., 76, 10 (2000).

11. M.A.Garcia, J.Phys.D:Appl.Phys.,

44, 283001 (2011).

12. Silver Nanoparticles, ed. D.P.Perez, In-Tech, Vukovar, Croatia (2010).

13. A.V.Red'kov, Phys.Sol.State, 54, 1875 (2012).

14. P.A.Obraztsov, A.V.Nashchekin, N.V.Nikonorov et al., Phys.Sol.State, 55, 1272 (2013).

15. W.Soppe, F.Aldenkamp, H.W.Hartog, J.NonCryst.Sol., 91, 351 (1987).

16. R.E.Youngman, J.W.Zwanziger, J.Non-Cryst. Sol., 168, 293 (1994).

17. R.E.Youngman, S.T.Haubrich, J.W.Zwanziger et al., Science, 269, 1416 (1995).

18. K.Terashima, S.-H.Kim, T.Yoko, J.Ceram. Soc., 76, 1601 (1995).

19. Ch.Chen, Y.Wu, R.Li, Intern. Rev. in Physю Сиетю, 8, 65 (1989).
20. M.Abdel-Baki, F.A.Abdel-Wahab, F.El-Diasty, J.Appl. Phys., 111, 073506 (2012).

21. I.M.Bolesta, O.O.Kushnir, I.I.Kolych et al., Adv. Sci.Eng. Med., 6, 326 (2014).

22. V.T.Adamiv, I.M.Bolesta, Ya.V.Burak et al., Physica B: Phys.Cond.Matter., 449C, 31 (2014).

23. V.T.Adamiv, Ya.V.Burak, R.V.Gamernyk et al., Functional Materials, 18, 298 (2011).

24. S.S.Rojas, J.E.De Souza, K.Yukimitu, A.C.Hernandec, J.Non-Cryst.Sol., 398-399, 57 (2014).

25. V.T.Adamiv, Ya.V.Burak, I.S.Girnyk, I.M.Teslyuk, Functional Materials, 20, 52 (2013).

26. M.Sheik-Bahae, A.A.Said, E.W.Van Stryland, Opt.Lett., 14, 955 (1989).

27. M.Sheik-Bahae, A.A.Said, T.H.Wei et al., IEEE J.Quant. Electron., QE-26, 760 (1990).

28. M.Narajan, R.Faggini, I.O.Brown, Cryst. Struct.Commun., 8, 367 (1979).

29. A.Senyshyn, H.Boysen, R.Niewa et al., $J$. Phys. D:Appl. Phys., 45, 175305 (2012).

30. N.V.Zayakina, A.A.Brovkin, Sov.Phys.Crystallogr., 22, 275 (1977).

31. B.V.Padlyak, S.I.Mudry, Y.O.Kulyk et al., Mater. Sci., Poland., 30, 264 (2012).

32. J.M.Fernandez Navarro, J.Toudert, Y.Rodriguez-Lazcano et al., Appl.Phys. B, 113, 205 (2013).

33. G.V.Arnold, J.Appl.Phys., 46, 4466 (1975).

34. S.S.Rojas, K.Yukimitu, A.S.S. de Camargo et al., J.Non-Cryst.Sol., 352, 3608 (2006). 